\title{
Carbon balance and energy fluxes of a Mediterranean crop
}

\author{
Simona Consoli, ${ }^{1}$ Osvaldo Facini, ${ }^{2}$ Antonio Motisi, ${ }^{3}$ Marianna Nardino, ${ }^{2}$ Rita Papa, ${ }^{1}$ \\ Federica Rossi, ${ }^{2}$ Salvatore Barbagallo' \\ ${ }^{1}$ Dipartimento di Gestione dei Sistemi Agro-alimentari e Ambientali (DiGeSA), Università degli \\ Studi di Catania, Italy; ${ }^{2}$ Istituto di Biometeorologia, Consiglio Nazionale delle Ricerche, Bologna, \\ Italy; ${ }^{3}$ Dipartimento Scienze Agrarie e Forestali (SAF), Università degli Studi di Palermo, Italy
}

\begin{abstract}
This paper is based on the analysis of a long-term mass (carbon dioxide, water vapour) and energy (solar radiation) balance monitoring programme carried out during years 2010 and 2012 in an irrigated orange orchard in Sicily, using the Eddy Covariance (EC) method. Orange (Citrus sinensis L.) is one of the main fruit crops worldwide and its evergreen orchard may have a great potential for carbon sequestration, but few data are currently available. In the study, the role of the orchard system in sequestering atmospheric $\mathrm{CO}_{2}$ was analyzed, thus contributing to assess the carbon balance of the specie in the specific environment.Vertical energy fluxes of net radiation, soil heat, sensible heat and latent heat fluxes were measured at orchard scale by EC. Evapotranspiration (ET) values were compared with upscaled transpiration data determined by the sap flow heat pulse technique, evidencing the degree of correspondence between instantaneous transpirational flux at tree level and the micrometeorological measurement of ET at orchard level.
\end{abstract}

\section{Introduction}

Correspondence: Simona Consoli, Dipartimento di Gestione dei Sistemi Agro-alimentari e Ambientali (DiGeSA), Università degli Studi di Catania, via S. Sofia 100, 95123 Catania, Italy.

Tel. +39.095 .7147547 - Fax: +39.095 .7147605 .

E-mail: simona.consoli@unict.it

Key words: carbon balance, eddy covariance, orange orchard.

Acknowledgements: this work has been carried out in the context of the Project of Relevant National Interest (P.R.I.N.) 2008 "Assessment of mass and energy fluxes for the irrigation management of Mediterranean tree crops" under grant no. 2008CR84NF by Italian Ministry of Research and University (M.I.U.R.). Authors wish to thank the Azienda Tribulato (Lentini, SR) for its hospitality. Authors are also grateful to the Agrometeorological Service (SIAS) of the Sicilian Region for its support.

(C) Copyright S. Consoli et al., 2013

Licensee PAGEPress, Italy

Journal of Agricultural Engineering 2013; XLIV(s2):e6

doi:10.4081/jae.2013.s2.e6

This article is distributed under the terms of the Creative Commons Attribution Noncommercial License (by-nc 3.0) which permits any noncommercial use, distribution, and reproduction in any medium, provided the original author(s) and source are credited.
Orange orchards are widely diffused in Mediterranean regions, playing a fundamental role in the economy of the primary sector of these areas (Capra et al., 2011). These species need a large amount of water for sustaining their production, and the determination of their effective water demand is still an important issue of debate in the applied research (Hamdy, 1999; Consoli et al., 2006; Consoli and Papa, 2012; Ballester et al., 2012), similarly to the partition of crop evapotranspiration $\left(\mathrm{ET}_{\mathrm{c}}\right.$ ) into transpiration ( $\mathrm{T}$ ) and soil evaporation (E) rates (Cohen et al., 1993; Rana et al., 2005; Consoli and Papa, 2012; Motisi et al., 2012). The role of these species from an ecological point of view in terms of absorbing the atmospheric carbon dioxide $\left(\mathrm{CO}_{2}\right)$ is much less discussed and few data are available in the literature. Recent research carried out on the role of Mediterranean orchards (olive and orange) in sequestering atmospheric $\mathrm{CO}_{2}$ have evidenced them to be high carbon sinks, with respect to other evergreen orchards (Liguori et al., 2009; Nardino et al., 2013). In general, the efficiency of the orchards as carbon sink is favoured by its vigorous growth and high leaf area index, even if human actions (farming management techniques) may influence their physiology and thus carbon sequestration role. Modern concepts of intensive agricultural crop systems and highly efficient irrigation management strategies (i.e. drip irrigation, deficit irrigation, etc...) lead to an intensification of the orange eco-physiological activity and potential carbon sequestration, driving towards advances in crop productivity (Pernice et al., 2009).

The study of the physical relationships between orange orchards and the atmosphere above, allowing the comprehension of the exchange mechanisms of water, carbon dioxide and heat, presents several constraints related to the homogeneous extensions to match the required fetch, the expensive micrometeorological tower to put in operation, and often the complexity of data processing. The Eddy Covariance (EC) technique constitutes the reference method to monitor and measure the above cited flux exchange mechanisms; although its adoption in monitoring networks throughout the world has led to significant advances in defining how ecosystem-level fluxes respond to variability in land cover and climate forcing (Baldocchi, 2003), it is influenced by a series of restrictive assumptions requiring corrections, including: surface homogeneity of the downwind area, sensor misalignment, air density changes, coordinate rotation, etc. Thus, recorded EC data need validation to be representative. Furthermore the inability of EC data to close the energy budget is a well-known issue (Aubinet et al., 2000; Barr et al., 2006; Twine et al., 2000), which has led several authors to emphasize the necessity of finding a way to deal with it (Mahrt, 1998; Wilson et al., 2002; Baldocchi, 2003; Liu et al., 2006, Consoli and Papa, 2012). Despite the sources of errors associated with long-term EC flux measurements, many investigators are producing reasonable estimates of annual carbon exchange. When measurements come from nearly ideal sites the error bound on the net annual exchange of $\mathrm{CO}_{2}$ is less than $\pm 50 \mathrm{~g}(\mathrm{C}) \mathrm{m}^{-2}$ year $^{-1}$ (Baldocchi, 2003).

This paper aims at analysing the mass $\left(\mathrm{H}_{2} \mathrm{O}, \mathrm{CO}_{2}\right)$ and heat fluxes 
exchanged within an orange orchard in Sicily to (i) assess the carbon balance and the role of the orchard system in sequestering atmospheric $\mathrm{CO}_{2}$; and (ii) determine reliable crop water demand values to be partitioned between crop transpiration and soil evaporation rates.

\section{Materials and Methods}

The experimental field, which had an area of approximately 20 ha, is located in Eastern Sicily, where orange orchards are the predominant crop. The plants (15-25 years-old Citrus sinensis, cv Tarocco Ippolito) are on a regular grid of $4.0 \times 5.5 \mathrm{~m}^{2}$ (about 455 plants ha-1); the mean canopy height is $3.7 \mathrm{~m}$ and the crop ground cover is $70 \%$, with a mean leaf area index (LAI) of $4.3 \mathrm{~m}^{2} \mathrm{~m}^{-2}$, measured by an LAI-2000 Plant Canopy Analyzer (Li-Cor Bioscence, USA). Trees were daily drip irrigated at full rate with four on-line drippers per plant (discharge rate of $4 \mathrm{l}$ $\mathrm{h}^{-1}$ ). The total volume of water applied during summer was fixed at $5,500 \mathrm{~m}^{3} \mathrm{ha}^{-1}$ and added to precipitation amounts. The site shows good crop homogeneity, no slope, and dominant wind speed and fetch allowing for an ideal application of micrometeorological techniques (Figure 1). During the monitoring period 2010-2012, hourly meteorological data (incoming short-wave solar radiation, air temperature, air humidity, wind speed and rainfall) have been acquired by an automatic weather station located near the orchard (about $7 \mathrm{~km}$ far) and managed by SIAS (Servizio Informativo Agrometeorologico Siciliano). The wind data recorded from this station were considered during the tower setting up, with the prevailing wind direction determined to be west (Figure 2).

The Eddy Covariance technique (Swinbank, 1951; Aubinet et al., 2000 ) was used to directly measure the vertical fluxes of $\mathrm{CO}_{2}, \mathrm{H}_{2} \mathrm{O}$ and sensible heat, $\mathrm{H}$, for three consecutive years (from January 2010 to December 2012). A 10 meter mast set up equipped with two 3-dimensional sonic anemometers (Windmaster Pro, Gill Instruments Ltd, at $4 \mathrm{~m}$, and a CSAT-3D, Campbell Sci. USA, at $8 \mathrm{~m}$ ) and an open path gas analyzer (IRGA) (Li7500, LiCor Inc., USA) was positioned in the orchard. The net available energy $\left(\mathrm{R}_{\mathrm{N}}, \mathrm{W} \mathrm{m}^{-2}\right)$ at the surface was measured by a four-component net radiometer (CNR1, Kipp\&Zonen) deployed at about 8 meters from the ground. Soil heat flux density (G, $\mathrm{W} \mathrm{m}^{-2}$ ) was measured with three soil heat flux plates (HFP01, Campbell Scientific Ltd) placed horizontally $0.05 \mathrm{~m}$ below the soil surface. Three different measurements of $\mathrm{G}$ were selected: in the trunk row (shaded area), at $1 / 3$ of the distance to the adjacent row, and at $2 / 3$ of the distance to the adjacent row. The soil heat flux was measured as the mean output of three soil heat flux plates. Data from the soil heat flux plates was corrected for heat storage in the soil above the plates.

The raw data was recorded at a frequency of $10 \mathrm{~Hz}$ using two synchronized data loggers (CR3000, Campbell Sci.) and data quality was checked during the post processing together with some routines to remove the common errors (Kaimal and Finnigan, 1994).

Unfortunately, during 2011, most data from the gas analyzer were lacking due to necessary maintenance. This loss of $\mathrm{CO}_{2}$ and $\mathrm{H}_{2} \mathrm{O}$ data did not allow to elaborate on carbon and energy balances.

Within the footprint area of the tower, plant transpiration rate was measured by applying the Heat Pulse Velocity (HPV) sap flow technique (Green and Clothier, 1988).

When high frequency micrometeorological fluxes were checked for quality, the percentage of data coverage may have been reduced; thus, procedures of data gap filling were often applied determining the annual and monthly net ecosystem exchange (NEE). In the study, a non linear regression method was applied for filling the gaps (Falge et al., 2001). Missing values of $\mathrm{CO}_{2}$ flux $\left(\mathrm{F}_{c}, \mathrm{mmol} \mathrm{m}^{-2} \mathrm{~s}^{-1}\right)$ were calculated using the regression relationship established between $\mathrm{F}_{\mathrm{c}}$ and measured air temperature (nightime) and radiation (daytime) on monthly bases.

For nocturnal respiration fluxes, the Lloyd and Taylor (1994) relation was applied:

$$
\mathrm{R}_{\mathrm{e}}=\mathrm{b}_{1} \mathrm{e}^{\mathrm{b} 2 \mathrm{~T}_{\mathrm{air}}}
$$

where, $R_{\mathrm{e}}\left(\mu \mathrm{mol} \mathrm{m} \mathrm{m}^{-2} \mathrm{~s}^{-1}\right)$ is the ecosystem respiration and $\mathrm{b}_{1}$ and $\mathrm{b}_{2}$ are the coefficients computed for each month from the experimental data (data not showed). For diurnal fluxes $\left(\mathrm{F}_{\mathrm{c}}\right)$, the equation of Dagnelie (1991) was adopted:

$$
F_{c}=G P P_{O P T}\left(1-e^{\frac{a P P F D}{G P P}}\right)-R_{\text {day }}
$$

where, PPFD is the photosynthetic photon flux density, a is a coefficient, GPP is the gross primary production and $R_{\text {day }}$ the diurnal ecosystem respiration.

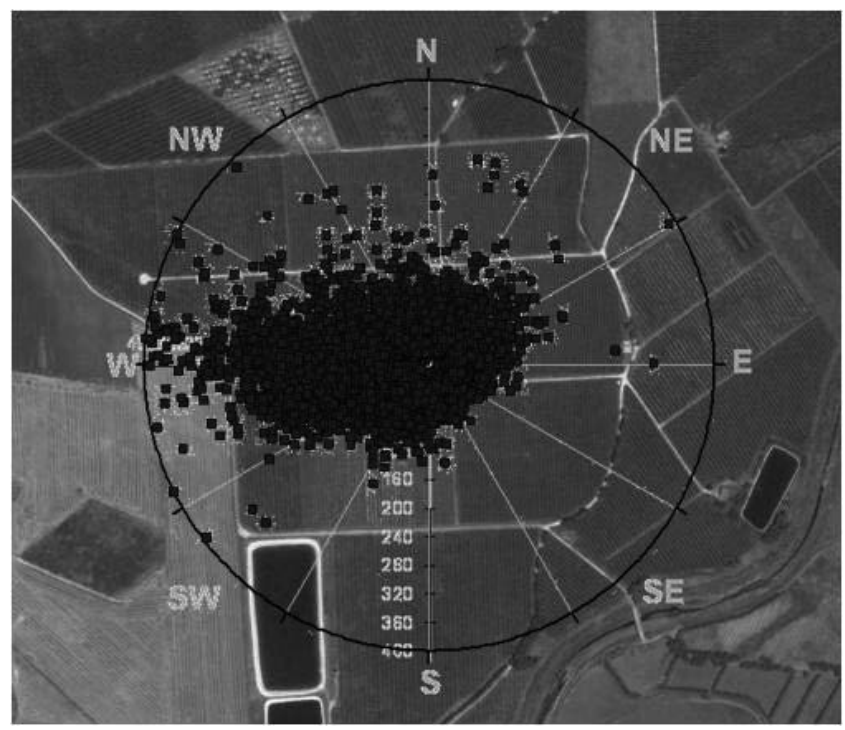

Figure 1. Footprint area (A) where points denote downwind distance where fluxes were mainly captured by the micrometeorological tower; (B) wind rose for a $10^{\circ}$ wind sector expressed as a percent of the data over a 5-year period.

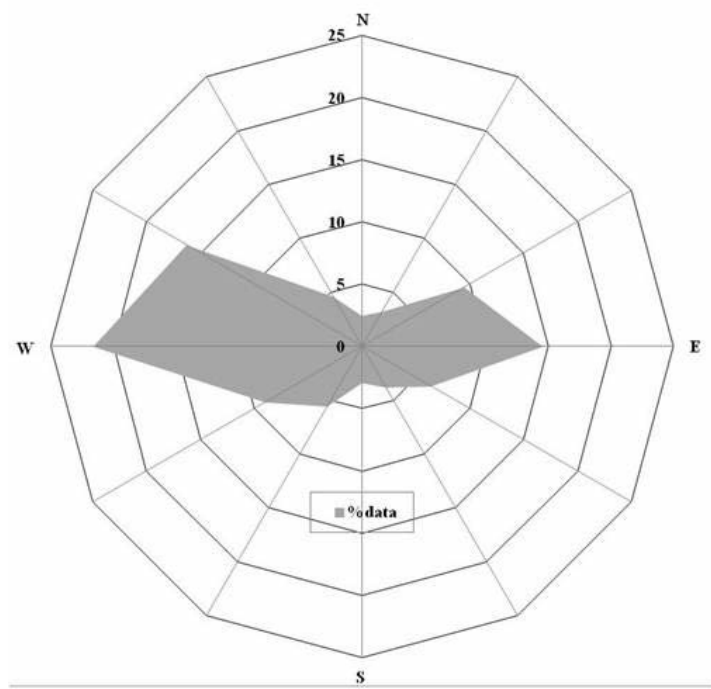

Figure 2. Micrometeorological tower and sap flow sensors location. 
Total carbon exchange terms were estimated both at monthly and annual scales. The NEE was computed from the complete series of $\mathrm{CO}_{2}$ fluxes measured by EC and gap filled using the nonlinear regression method described above. The ecosystem respiration (ER) was estimated according to Falge et al. (2001), with the Lloyd and Taylor's equation. In particular, there is negligible photosynthesis at night, so nightime NEE is a measure of ER (Desai et al., 2005).

The gross primary productivity for each $30 \mathrm{~min}$ was the difference between NEE and estimated ER.

Additionally, surface energy balance measurements at the experimental site showed that the sum of sensible and latent (LE) heat flux was highly correlated $\left(r^{2}>0.90\right)$ (Figure 3$)$ to the sum of net radiation and soil heat flux. A linear fit between the two quantities showed a certain energy balance un-closure for 2010 and 2012. These percentages of un-closure are in the range reported by most flux sites (Wilson et al., 2002) and provide additional confirmation of the turbulent flux quality (Moncrieff et al., 1996).

Measurements of water consumption at tree level $\left(\mathrm{T}_{\mathrm{SF}}\right)$ were done by using the Heat Pulse Velocity (HPV) technique. For HPV measurements, two $4 \mathrm{~cm}$ sap flow probes with 4 embedded thermocouples (Tranzflo NZ Ltd, Palmerston North, NZ) were inserted into the trunks of three trees. The probes were positioned at the North and South sides of the trunk at $50 \mathrm{~cm}$ from the ground and wired to a data-logger (CR1000, Campbell Sci.) for heat-pulse control and measurement; the sampling interval was $30 \mathrm{~min}$. Data from the two probes was processed according to Green et al. (2003) to integrate sap flow velocity over sapwood area and to calculate transpiration. Therefore, the sapwood fraction of water was determined both on sample trees during the experiment, and directly on the trees with the sap flow probes, at the end of the observation period. Wound-effect correction (Green et al., 2003) was done on a per-tree basis.

Scaling up the sap flow from a single tree to the field scale requires analysing plant size variability, to determine the mean of those monitored. This was obtained by analysing the spatial variability of plant leaf area (Jara et al., 1998). Thus, scaling was done only on the basis of the ratio between orchard leaf area index (LAI) and tree leaf area.

\section{Results and Discussion}

Precipitation and temperature regimes were fairly similar during the 3 experimental years, and were typical of a Mediterranean area, with a mean air temperature of about $18.0^{\circ} \mathrm{C}$ and annual rainfall less than 600 $\mathrm{mm}$. The diurnal flux trend of individual components of the energy balance for the orange orchard showed that the latent heat flux was always in excess of the sensible heat flux during daylight hours and the $\mathrm{H}$ was higher than the soil heat flux. At night, the Eddy Covariance results showed $\mathrm{H}$ and LE approaching zero (Figure 4).

During typical days of the spring-summer periods (Figures 5 and 6), latent heat (or evapotranspiration) was generally (with the exception of April) the prevalent flux, with a weak midday depression, most likely due to no limit in crop water availability.

The orchard photosynthetic activity $\left(F_{c}, \mu m o l m^{-2} \mathrm{~s}^{-1}\right)$ showed the typical trend of the evergreen species. Maximum values were observed during May-June and August-September periods; the month of July of the study period was characterized by a reduction in the crop photosynthetic activity, with a shift in the maximum assimilation towards the first daytime hours; this was most likely due to the rise in air temperature, causing stomatal closure.

The net ecosystem exchange was calculated at monthly and annual scales. Figure 7 shows the monthly NEE, ecosystem respiration and gross primary production together with air temperature and cumulative precipitation during 2010 and 2012 periods. The highest NEE values were recorded during the spring-summer period $\left[90-100 \mathrm{~g}(\mathrm{C}) \mathrm{m}^{-2}\right.$ month $^{-1}$ ]. ER ranged from 40 to $110 \mathrm{~g}(\mathrm{C}) \mathrm{m}^{-2}$ month ${ }^{-1}$, reaching maximum values during the spring and the autumn. The highest values of ecosystem assimilation (GPP) was $180 \mathrm{~g}(\mathrm{C}) \mathrm{m}^{-2}$ month $^{-1}$ in May 2010 and $140 \mathrm{~g}(\mathrm{C}) \mathrm{m}^{-2}$ month $^{-1}$ in the April-June period 2012, the lowest values were in the December-February period of both years.
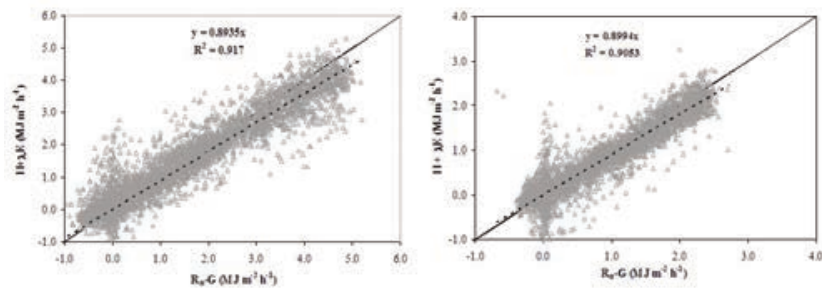

Figure 3. Surface energy balance closure from EC measurements during 2010 and 2012.

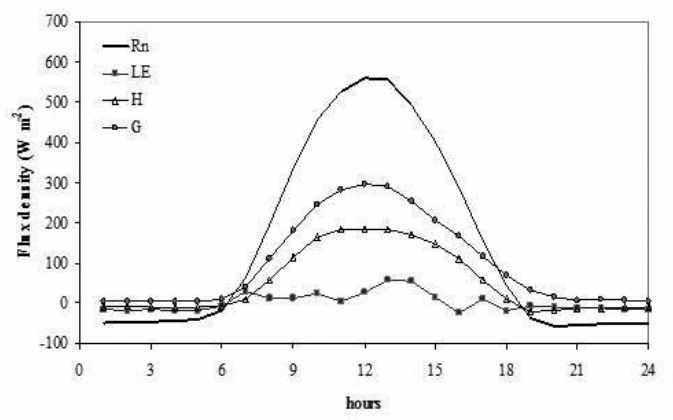

Figure 4. Surface energy balance components during a typical summer day in the experimental period.
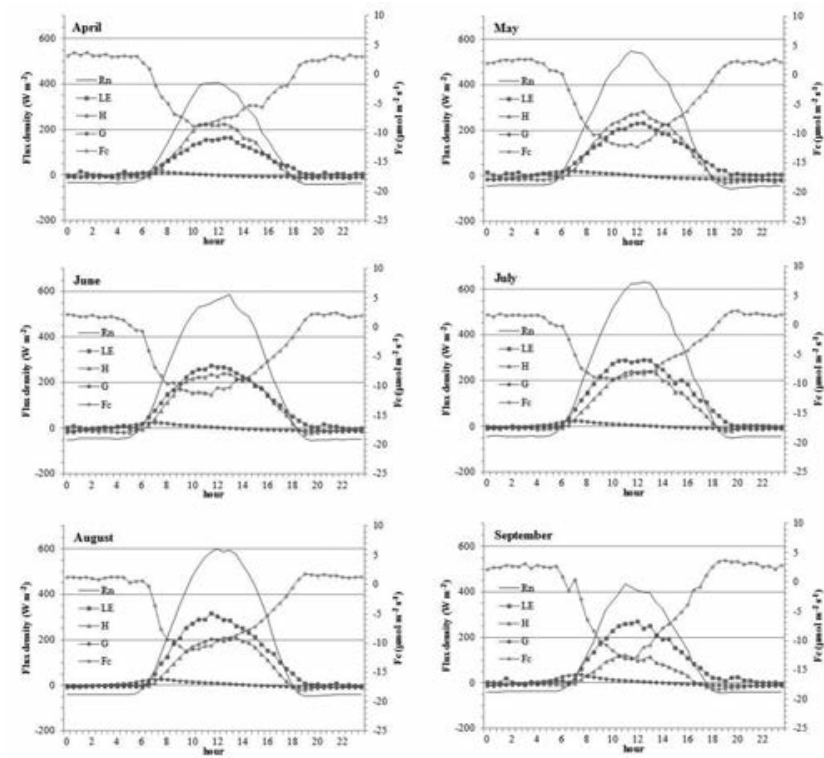

Figure 5. Surface energy balance components and $\mathrm{CO}_{2}$ fluxes during typical spring-summer days in 2010. 


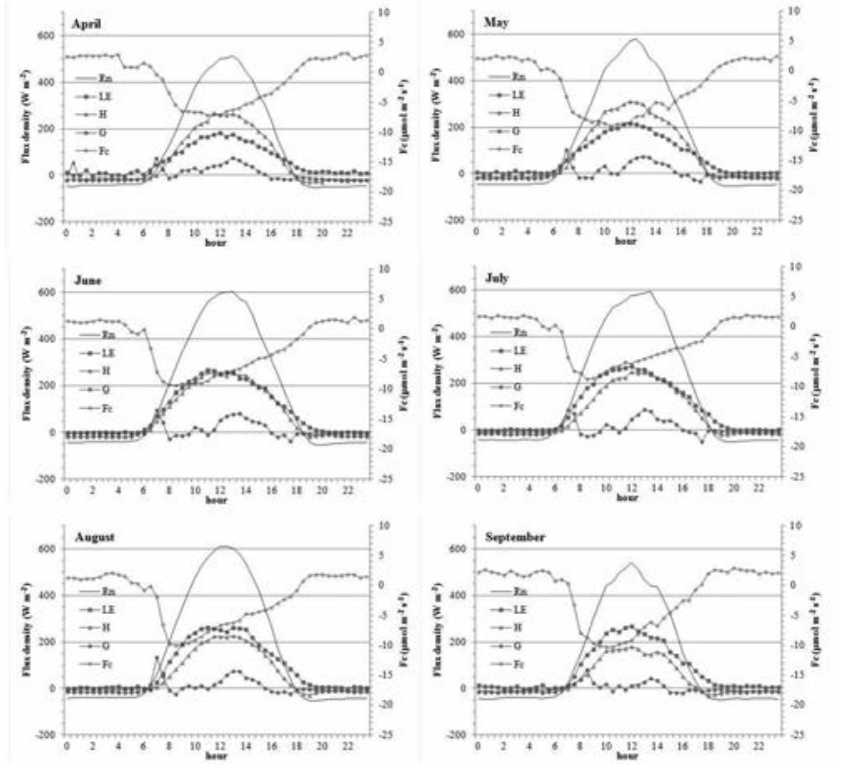

Figure 6. Surface energy balance components and $\mathrm{CO}_{2}$ fluxes during typical spring-summer days in 2012.
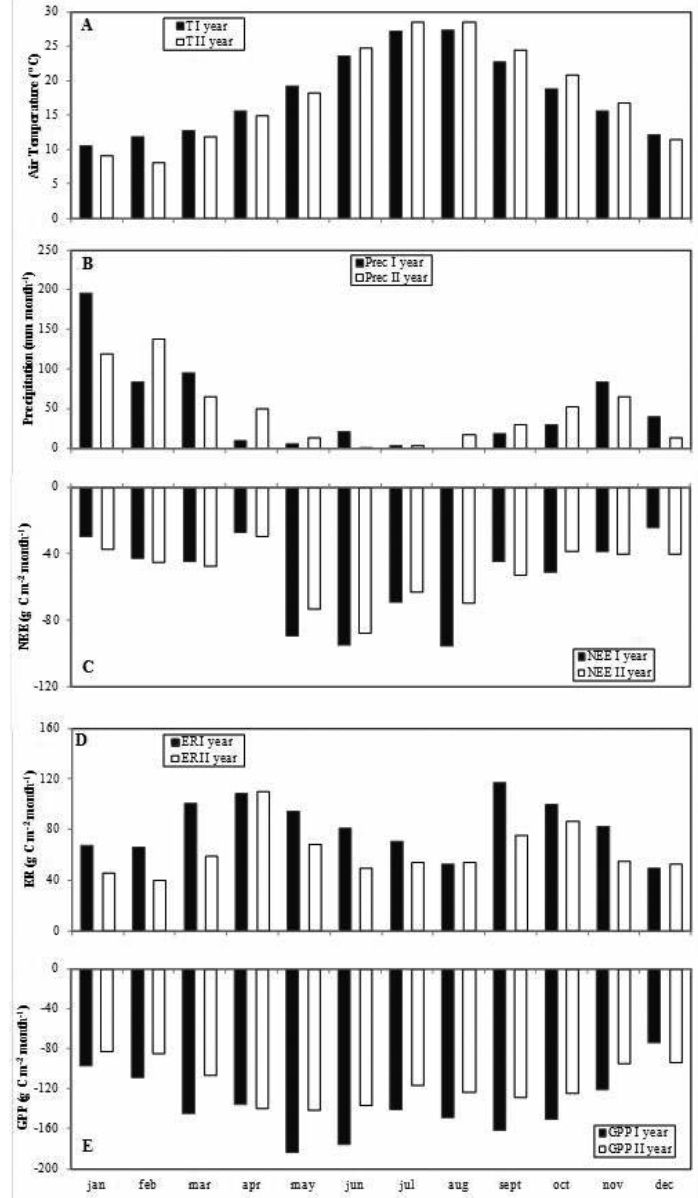

Figure 7. Monthly trends of air temperature (A), cumulative precipitation $(B)$, net ecosystem exchange (C), ecosystem respiration (D) and gross primary production (E) during 2010 and 2012.
The annual carbon uptake of the orange orchard under study was 6.5 $\mathrm{t}(\mathrm{C}) \mathrm{ha}^{-1}$ year $^{-1}$ in 2010 and $6.3 \mathrm{t}(\mathrm{C}) \mathrm{ha}^{-1}$ year-1 $^{-1}$ in 2012 (Figure 8). Total ER was $9.9 \mathrm{t}(\mathrm{C}) \mathrm{ha}^{-1}$ year ${ }^{-1}$ in 2010 and $7.5 \mathrm{t}(\mathrm{C}) \mathrm{ha}^{-1}$ year $^{-1}$ in 2012. Consequently, gross primary production was $16.4 \mathrm{t}(\mathrm{C}) \mathrm{ha}^{-1}$ year $^{-1}$ in 2010 and $13.7 \mathrm{t}(\mathrm{C}) \mathrm{ha}^{-1}$ year $^{-1}$ in 2012.

On the whole, the carbon balance during the two years under study was quite similar, indicating similar plant functionality. This corroborates with the same climatic conditions during the examined periods (Figure $7 \mathrm{~A}$ and $\mathrm{B}$ ).

The divergence between sap flow transpiration values and crop evapotranspiration begins at about 09:00 local time. Midday $\mathrm{T}_{\mathrm{SF}}$ fluxes were almost steady for most of the period while $\mathrm{ET}_{\mathrm{c}}$ ones followed the daily trend of atmospheric evapotranspiration demand (Figure 9). Midday differences between $\mathrm{T}_{\mathrm{SF}}$ and $\mathrm{ET}_{\mathrm{c}}$ denote a depletion of plant water content in relation to the imbalance between tree crown water loss by transpiration, as estimated by EC, and water transport from the tree's root mass as estimated by sap flow (SF). This imbalance is recovered in the afternoon and nocturnal hours, with higher $\mathrm{T}_{\mathrm{SF}}$ than $\mathrm{ET}_{\mathrm{c}}$ fluxes. Most of the differences here in water-use dynamics could be interpreted by tree capacitance. The imbalance between canopy transpiration and treewater uptake is revealed by a large hysteresis (data not shown), with higher afternoon SF values. It is interesting to note that the hysteresis loop appears specularly reflected, with a larger hysteresis in the morning-midday hours (Motisi et al., 2012). During 2012, a decreasing trend was observed on plant $\mathrm{T}_{\mathrm{SF}}$ values, associated with the inability to recover the daily imbalance between EC estimation of water losses and those estimated by SF. This fact most likely reflects the first symptoms of physiological diseases caused by the CTV virus, that was described to have influenced the crop from the end of 2011 The cumulative values of $\mathrm{ET}_{\mathrm{c}}$ and sap flow measurements of transpiration in the MaySeptember periods were about $600 \mathrm{~mm}$ and $530 \mathrm{~mm}$, respectively.. The average daily values of $\mathrm{ET}_{\mathrm{c}}$ and $\mathrm{T}_{\mathrm{SF}}$ are $3.9 \mathrm{~mm} \mathrm{~d}^{-1}$ and $3.4 \mathrm{~mm} \mathrm{~d}^{-1}$, dur-

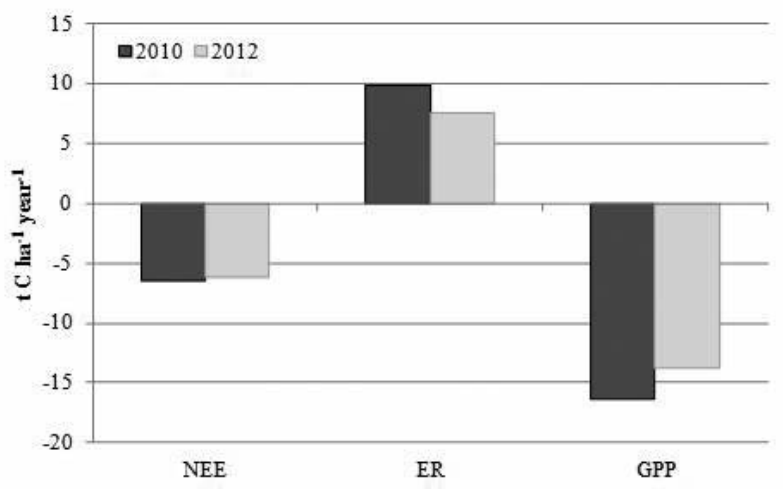

Figure 8. Net ecosystem exchange (NEE), ecosystem respiration (ER) and gross primary production (GPP) in 2010 and 2012.
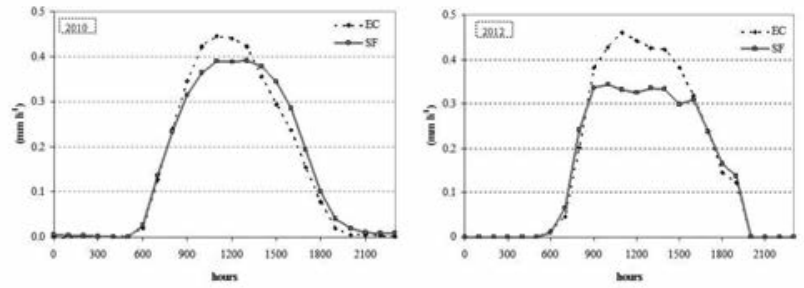

Figure 9. Diurnal changes of up-scaled sap flow (SF) fluxes in orange. Each datapoint represents the average of all the values in the observation period (July-August 2010 and 2012). 
ing May-October 2010 and $4.0 \mathrm{~mm} \mathrm{~d}^{-1}$ and $3.5 \mathrm{~mm} \mathrm{~d}^{-1}$ in 2012.

The values of $\mathrm{ET}_{\mathrm{c}}$ followed atmospheric demand in both growing seasons, being higher during May-October (from flowering to fruit maturation), with peaks of $6.7 \mathrm{~mm} \mathrm{~d}^{-1}$ and $6.0 \mathrm{~mm} \mathrm{~d}^{-1}$ during 2010 and 2012 .

\section{Conclusions}

The orange orchard under study has the typical configuration of an intensive system, with about $70 \%$ of ground cover by the vegetation. For this system, the net ecosystem exchange and ecosystem respiration were computed from the complete series of the $\mathrm{CO}_{2}$ fluxes measured by the Eddy Covariance method. The NEE measured for the orchard during the study were $6.5 \mathrm{t}(\mathrm{C}) \mathrm{ha}^{-1}$ year $^{-1}$ in 2010 and $6.3 \mathrm{t}(\mathrm{C}) \mathrm{ha}^{-1}$ year $^{-1}$ in 2012 , similar to those reported for the same crop by Liguori et al. (2009). NEE and ER variations were mainly related to the fluctuation of the meteorological variables at the experimental site. In particular, in the region under study, carbon exchanges were driven by the available radiation and water. However, the scarcity of information on the NEE of fruit tree orchards does not allow a comparative analysis between various species and orchard management practices.

The Eddy Covariance technique allowed to assess water, energy and carbon exchanges from the plant system and it is proved reliable in providing information at the orchard scale and at different temporal scales. Its results are fairly well coupled with transpiration measurements through sap flow.

In conclusion, these preliminary results may allow assessing the sink capacity of an important crop system that is widely present in the Mediterranean agricultural context.

\section{References}

Aubinet M; Grelle A; Ibrom A; Rannik Ü; Moncrieff J; Foken T; Kowalski AS; Martin PH; Berbigier P; Bernhofer Ch; Clement R; Elbers J; Granier A; Grünwald T; Morgenstern K; Pilegaard K; Rebmann C; Snijders W; Valentini R; Vesala T. 2000. Estimates of the net annual carbon and water exchange of forests: the EUROFLUX methodology. Adv. Ecol. Res., 30, 113175.

Baldocchi DD. 2003. Assessing the ed dy covariance technique for evaluating carbon dioxide exchange rates of ecosystems: past, present and future. Global Change Biol., 9, 479-492.

Ballester C; Castel J; Intrigliolo DS; Castel JR. 2012. Response of Navel Lane Late citrus trees to regulated deficit irrigation: yield components and fruit composition. Irrigation Science, 31, 333-341.

Barr AG; Morgenstern K; Black TA; McCaughey JH; Nesic Z. 2006. Surface energy balance closure by the eddy-covariance method above three boreal forest stands and implications for the measurement of the $\mathrm{CO}_{2}$ flux. Agric. Forest Meteorol., 140, 322-337.

Capra A; Consoli S; Scicolone B. 2011. Economic analysis of citrus orchards under deficit irrigation in South Italy. ISHS Acta Horticulturae 922. XXVIII International Horticultural Congress on Horticulture for People (IHC2010).

Cohen M; Girona J; Valancogne C; Ameglio T; Cruizat P; Archer P. 1993. Water consumption and optimisation of the irrigation in orchards. Irrig. Sci., 12(2), 93-98.

Consoli S; O'Connell NV; Snyder RL. 2006. Estimation of evapotranspiration of different orange sized orchard canopies using energy balance. J. Irr. Drain. Eng. ASCE, 32(1), 2-8.

Consoli S; Papa R. 2012. Corrected surface energy balance to measure and model the evapotranspiration of irrigated orange orchards in semi-arid
Mediterranean conditions. Irrig. Sci., ISSN 0342-7188, DOI 10.1007/s00271-012-0395-4.

Dagnelie P. 1991. Theorie et methodes statistiques. Presses Agronomiques de Gembloux, Vol.1.

Desai AR; Bolstad PV; Cook BD; Davis KJ; Carey EV. 2005. Comparing net ecosystem exchange of carbon dioxide between an old-growth and mature forest in the upper Midwest, USA. Agri. For. Meteorol. 128, 33-55.

Falge E; Baldocchi DD; Olson RJ; Anthoni P; Aubinet M; Bernhofer C; Burba G; Ceulemans R; Clement R; Dolman H; Granier A; Gross P; Grünwald T; Hollinger D; Jensen NO; Katul G; Keronen P; Kowalski AS; Ta Lai C; Law BE; Meyers T; Moncrieff J; Moors E; Munger JW; Pilegaard K; Rannik Ü; Rebmann C; Suyker A; Tenhunen J; Tu K; Verma S; Vesal a T; Wilson K; Wofsy S. 2001. Gap filling strategies for defensible annual sums of net ecosystem exchange. Agric. Forest Meteorol., 107, 43-69.

Green SR; Clothier B. 1988. Water use of kiwifruit vines and apple trees by the heat-pulse technique. J. Exp. Bot., 39, 115-123.

Green SR; Clothier B; Jardine B. 2003. Theory and Practical Application of Heat Pulse to Measure Sap Flow. Agron. J., 95, 1371-1379.

Hamdy A. 1999. Water resources in the Mediterranean region: from ideas to action. In: Background documentation for thematic session. Consultation of experts from MENA region on: World Water Vision-Water for Food and Rural Development. CIHEAM-IAMB, Valenzano, 27-29 May, pp. 1-23.

Jara J; Stockle CO; Kjelgaard J. 1998. Measurement of evapotranspiration and its components in a corn (Zea mays L.) field. Agr ic. Forest Meteorol., 92, 131-145.

Kaimal JC; Finnigan JJ. 1994. Atmospheric boundary layer flows. Oxford Univ. Press, pp. 289.

Liguori G; Gugliuzza G; Inglese P. 2009. Evaluating carbon fluxes in orange orchards in relation to planting density. J. Agr. Sci., 147, 637-645.

Liu H; Randerson JT; Lindfors J; Massman W; Foken T. 2006. Consequences of incomplete surface energy balance closure for $\mathrm{CO} 2$ fluxes f rom open-path C02/H2O infrared gas analyzers. Bound.-Layer Meteorol., 120, 65-85.

Lloyd J; Taylor J.A. 1994. On the temperature dependence of soil respiration. Funct. Ecol., 8, 315-323.

Mahrt L. 1998. Flux sampling errors for aircraft and towers. J. Atmos. Oceanic Technol., 15, 416-429.

Moncrieff JB; Malhi Y; Leuning R. The propagation of errors in long-term measurements of land-atmosphere fluxes of carb on and water. 1996. Global Change Biol., 2, 231-240.

Motisi A; Consoli S; Rossi F; Minacapilli M; Cammalleri C; Papa R; Rallo G; D'Urso G. 2012. Eddy covariance and sap flow measurements of energy and mass exchange of woody crops in a Mediterranean environment. In: $8^{\text {th }}$ international workshop on sap flow, Volterra, May 8-12.

Nardino M; Pernice F; Rossi F; Georgiadis T; Facini 0; Motisi A; Drago A. 2013. Annual and monthly carbon balance in an intensively managed Mediterranean olive orchard. Photosynthetica, 51(1), 63-74.

Pernice F; Motisi A; Rossi F; Georgiadis T; Nardino M; Fontana G; Dimino G; Drago A. 2009. Micrometeorological and sap flow measurements of water vapour exchanges in olive: scaling up from canopy to orchard. Acta Hort., 846, 159-166.

Rana G; Katerji N; de Lorenzi F. 2005. Measurement an d modelling of evapotranspiration of irrigated citrus orchard under Mediterranean conditions. Agric. Forest Meteorol., 128, 199-209.

Swinbank, WC. 1951. The measurement of vertical transfer of heat and water vapour by eddies in the lower atmosphere. J. Meteorol., 8, 135-145.

Twine TE; Kustas WP; Norman JM; Cook DR; Houser PR; Meyers TP; Prueger JH; Starks PJ; Wesely ML. 2000. Correcting eddy-covarianc e flux underestimates over a grassland. Agric. Forest Meteorol., 103, 279-300.

Wilson K; Goldstein A; Falge E; et al. 2002. Energy balance closure at fluxnet sites. Agric. Forest Meteorol., 113, 223-243. 